\title{
A screening for antimicrobial activities of Caribbean herbal remedies
}

\author{
Claribel Luciano-Montalvo ${ }^{1,4+}$, Isabelle Boulogne ${ }^{2}$ and Jannette Gavillán-Suárez ${ }^{1,3^{*+}}$
}

\begin{abstract}
Background: The TRAMIL program aims to understand, validate and expand health practices based on the use of medicinal plants in the Caribbean, which is a "biodiversity hotspot" due to high species endemism, intense development pressure and habitat loss. The antibacterial activity was examined for thirteen plant species from several genera that were identified as a result of TRAMIL ethnopharmacological surveys or were reported in ethnobotanical accounts from Puerto Rico. The aim of this study was to validate the traditional use of these plant species for the treatment of bacterial infections, such as conjunctivitis, fever, otitis media and furuncles.

Methods: An agar disc diffusion assay was used to examine five bacterial strains that are associated with the reported infections, including Staphylococcus saprophyticus (ATCC 15305), S. aureus (ATCC 6341), Escherichia coli (ATCC 4157), Haemophilus influenzae (ATCC 8142), Pseudomonas aeruginosa (ATCC 7700) and Proteus vulgaris (ATCC 6896), as well as the fungus Candida albicans (ATCC 752). The minimum inhibitory concentration (MIC) and minimum bactericidal concentration $(\mathrm{MBC})$ values were determined for each of the extracts that showed inhibitory activity.
\end{abstract}

Results: The decoctions of Pityrogramma calomelanos, Tapeinochilus ananassae, and Syzygium jambos, as well as the juice of Gossypium barbadense, showed $>20 \%$ growth inhibition against several bacteria relative to the positive control, which was the antibiotic Streptomycin. Extracts with the best antimicrobial activities were $S$. jambos that showed $\mathrm{MIC}=31 \mu \mathrm{g} / \mathrm{mL}$ and $\mathrm{MBC}=1.0 \mathrm{mg} / \mathrm{mL}$ against $P$. vulgaris and . ananassae that showed $\mathrm{MIC}=15 \mu \mathrm{g} / \mathrm{mL}$ against $S$. aureus.

Conclusion: This report confirms the traditional use of $P$. calomelanos for the treatment of kidney infections that are associated with stones, as well as the antimicrobial and bactericidal effects of $T$. ananassae against $P$. vulgaris and S. saprophyticus and the effects of S. jambos against S. aureus and S. saprophyticus.

Keywords: Ethnopharmacology, TRAMIL, Antibacterial, Syzygium jambos, Pityrogramma calomelanos, Tapeinochilus ananassae, Gossypium barbadense

\section{Background}

The plant-based formulations are a viable option that could be useful in reducing the side effects associated with conventional antibiotic treatment [1]. Plant-based formulations would also increase the number of compounds that are used to limit infections [2] and might function synergistically with current therapies [3]. Many

\footnotetext{
* Correspondence: jannette.gavillan@upr.edu

${ }^{\dagger}$ Equal contributors

'Institute of Interdisciplinary Research, University of Puerto Rico, Cayey, \#205 Antonio R. Barceló Ave, Cayey, PR 00736, Puerto Rico

${ }^{3}$ Department of Chemistry, University of Puerto Rico, Cayey, \#205 Antonio R. Barceló Ave, Cayey, PR 00736, Puerto Rico

Full list of author information is available at the end of the article
}

reports have identified anti-bacterial properties of plants, but these studies have primarily been conducted in Asia [4]. The Caribbean is one of the world's centers of biodiversity and endemism identified as a tropical mountainous "biodiversity hotspot" because "high species endemism combines with proportionally extensive habitat loss" [5]. Information regarding the use of herbal remedies in the Caribbean was obtained during TRAMIL (Traditional Medicines in the Islands) surveys. TRAMIL, which is a program of applied research focusing on popular medicine, was initiated in 1982 to understand, validate and expand primary health care practices based on the use of medicinal plants in the Caribbean. The

\section{Biomed Central}


TRAMIL program has a unique methodology that consists of ethnopharmacological surveys and bibliographic and experimental research. The TRAMIL program works to validate plant species, plant organs and methods of preparation that are recorded during TRAMIL surveys and that are used frequently, 20\% or more, for a particular ailment but are not documented in the scientific literature. The scientific validation of traditional health practices is based on criteria of safety and efficacy [6,7]. Moreover, TRAMIL organizes outreach activities (TRADIF) that are aimed at disseminating the results obtained from the efficacy and toxicity studies. Thus, the objectives and experience of TRAMIL in traditional Caribbean knowledge and the sustainable utilization of plants appear to be the best starting point to find interesting plants with antimicrobial potential.

In addition, plant species described in ethnobotanical accounts from Puerto Rico that are used to treat infections and as adjuvants for diabetes were included in this study $[8,9]$. There is evidence that diabetic patients suffer from high bacteremia levels due to high blood sugar levels that weaken the patient's immune system defenses [10] and increase the body's vulnerability to bacterial infections [11,12]. Consequently, the aim of this study was to validate the antimicrobial activity of herbal remedies that are used in the Caribbean to treat infections such as conjunctivitis, otitis media, kidney infections, and furuncles.

\section{Methods}

\section{Plant collection and identification}

All of the plants were collected in Puerto Rico. The specimens were numbered and deposited at the George Proctor Herbarium (SJ) in Puerto Rico. José Sustache, Botanist and Head of Puerto Rico Department of Natural and Environmental Resources Herbarium, classified the botanical species. The plant species that have been identified in the TRAMIL program and their traditional uses are the focus of the current study and are shown in Table 1.

\section{Plant material and preparation of decoctions, juices and aqueous extracts}

Decoctions were prepared by boiling $30 \mathrm{~g}$ of plant material in $100 \mathrm{~mL}$ of distilled water. After concentration to $15 \mathrm{~mL}$, to lyophilize $3 \times 5 \mathrm{~mL}$ replicates, the decoctions were filtered through cheesecloth, and freeze-dried using a Freezone 4.5 lyophilizer. Plant juices $(3 \times 5 \mathrm{~mL}$ replicates) were lyophilized after the plant part was crushed in a mortar and filtered through cheesecloth. The solids obtained after freeze-drying were re-dissolved in autoclaved water to known concentrations for antibacterial determination. The concentrations of the lyophilized extracts in $\mathrm{mg} / \mathrm{mL}$ were calculated as the average of the total solids obtained per $\mathrm{mL}$ of lyophilized decoction or plant juice. The plant part, preparation form, concentration of the re-dissolved extracts and the extraction yields are reported in Table 1.

\section{Disc preparation}

Whatman chromatography no 2 filter paper was used to prepare $6.3 \mathrm{~mm}$ paper discs that were incubated with $20 \mu \mathrm{L}$ aliquots of the re-dissolved extracts from lyophilized decoctions or juices at their final concentration and at 25\% and $50 \%$ dilutions, and air-dried for 2 hours, as described previously [13]. The positive controls were Streptomycin $(5 \mathrm{mg} / \mathrm{mL})$ and Nystatin $(50 \mathrm{mg} / \mathrm{L})$ for the antibacterial and antifungal assays, respectively. Distilled water was used as a negative control. The concentration of the extracts in the paper discs is reported in Table 1.

\section{Bacterial selection and culture}

The Caribbean Herbal Pharmacopeia [6], which is published by the TRAMIL program, established the experimental models that are required to validate antimicrobial activity. In this case, the antimicrobial activity had to be confirmed for at least one case. For agents associated with bacterial conjunctivitis, TRAMIL requires in vitro susceptibility studies of Haemophilus influenzae, Streptococcus pneumonia or Staphylococcus aureus. For otitis media, TRAMIL recommends the analysis of the effects of herbal remedies against the Gram-negative bacteria Escherichia coli, Pseudomonas aeruginosa or Proteus vulgaris; the Gram-positive bacterium S. aureus; and the fungus Candida albicans. E. coli is the primary causal agent of urinary tract infections (UTIs) and accounts for $>75 \%$ of community-acquired UTIs in all age groups, whereas Staphylococcus saprophyticus accounts for $10 \%$ of total UTIs [14]. Infections due to the presence of kidney stones are more commonly caused by urease-producing bacteria, such as S. aureus, Pseudomonas and Proteus. Finally, in the case of furuncle, which is an infection of the hair follicle, TRAMIL requires validation of antimicrobial activity against $\mathrm{S}$. aureus.

The test organisms included the Gram-positive bacteria Staphylococcus saprophyticus (ATCC 15305) and Staphylococcus aureus (ATCC 6341); the Gram-negative bacteria Escherichia coli (ATCC 4157), Haemophilus influenzae (ATCC 8142), Pseudomonas aeruginosa (ATCC 7700), and Proteus vulgaris (ATCC 6896); and the fungus Candida albicans (ATCC 752). The bacteria were maintained at $4^{\circ} \mathrm{C}$ on tryptic soy agar (TSA), and C. albicans (ATCC 752) was maintained on potato dextrose agar (PDA) (Difco, NJ, USA) before use. H. influenza (ATCC 8142) was incubated in the presence of a Gas-Pac (Becton and Dickinson Co, NJ, USA) with 5\% $\mathrm{CO}_{2}$. 
Table 1 Plant species recorded in ethnopharmacological/ethnobotanical surveys in the Caribbean that were examined for their antimicrobial and antifungal activities

\begin{tabular}{|c|c|c|c|c|c|c|c|c|}
\hline \multirow{2}{*}{$\begin{array}{l}\text { Scientific name/ } \\
\text { (voucher } \\
\text { specimen) }\end{array}$} & \multirow[t]{2}{*}{$\begin{array}{l}\text { Country/Traditional } \\
\text { use }^{\mathrm{a}}\end{array}$} & \multirow[t]{2}{*}{ Local name } & \multirow{2}{*}{$\begin{array}{l}\text { Plant parts } \\
\text { used/Preparation } \\
\text { form }\end{array}$} & \multirow[t]{2}{*}{$\begin{array}{c}\text { Extracts yield } \\
(\% \mathrm{w} / \mathrm{w})\end{array}$} & \multirow{2}{*}{$\begin{array}{l}\text { Concentration } \\
\text { of extracts } \\
(\mathrm{mg} / \mathrm{mL})\end{array}$} & \multicolumn{3}{|c|}{$\begin{array}{c}\text { Concentration of } \\
\text { extracts/disc }(\mu \mathrm{g} / \mu \mathrm{L})^{b}\end{array}$} \\
\hline & & & & & & Disc 1 & Disc 2 & Disc 3 \\
\hline $\begin{array}{l}\text { Cucurbitaceae } \\
\text { Cucurbita moschata } \\
\text { Duchesne (019344) }\end{array}$ & $\begin{array}{l}\text { Dominican Republic/ } \\
\text { skin burns }\end{array}$ & auyama & leaves/juice & 2.5 & 50.0 & 50.0 & 25.0 & 12.5 \\
\hline $\begin{array}{l}\text { Plantaginaceae } \\
\text { Plantago major L. } \\
\text { (019342) }\end{array}$ & $\begin{array}{l}\text { Nicaragua/kidney } \\
\text { infections }\end{array}$ & Ilantén & leaves/decoction & 1.4 & 28.7 & 28.7 & 14.3 & 7.2 \\
\hline $\begin{array}{l}\text { Labiatae Plectranthus } \\
\text { amboinicus (Lour.) } \\
\text { Spreng. (019352) }\end{array}$ & $\begin{array}{l}\text { Dominican Republic/ } \\
\text { otitis }\end{array}$ & orégano poleo & leaves/juice & 1.1 & 21.3 & 21.3 & 10.7 & 5.3 \\
\hline $\begin{array}{l}\text { Scrophulariaceae } \\
\text { Capraria biflora L. } \\
\text { (019353) }\end{array}$ & $\begin{array}{l}\text { Guadalupe, Marie- } \\
\text { Galante, Martinique, } \\
\text { Tobago/conjunctivitis }\end{array}$ & Té péyi, paye, titi, & leaves/decoction & 5.6 & 112.6 & 112.6 & 56.3 & 28.1 \\
\hline $\begin{array}{l}\text { Malvaceae } \\
\text { Abelmochus esculentus } \\
\text { (L.) Moench (019662) }\end{array}$ & $\begin{array}{l}\text { Dominican Republic/ } \\
\text { eye infections }\end{array}$ & molondrón & fruit/juice & 0.6 & 12.6 & 12.6 & 6.3 & 3.2 \\
\hline $\begin{array}{l}\text { Malvaceae Gossypium } \\
\text { barbadense L. } \\
\text { (019366) }\end{array}$ & Haiti/otitis media & koton & $\begin{array}{l}\text { leaves/decoction } \\
\text { unripe fruit/juice }\end{array}$ & $\begin{array}{l}5.5 \\
1.4\end{array}$ & $\begin{array}{c}110.5 \\
27.9\end{array}$ & $\begin{array}{l}110.5 \\
27.9\end{array}$ & $\begin{array}{l}55.3 \\
14.0\end{array}$ & $\begin{array}{l}27.6 \\
7.0\end{array}$ \\
\hline $\begin{array}{l}\text { Malvaceae Hibiscus } \\
\text { rosa-sinensis L. } \\
\text { (019535) }\end{array}$ & Haiti/conjunctivitis & choublak & flower/juice & 0.9 & 17.9 & 17.9 & 9.0 & 4.5 \\
\hline $\begin{array}{l}\text { Pteridaceae } \\
\text { Pityrogramma } \\
\text { calomelanos (L.) Link } \\
\text { (019372) }\end{array}$ & $\begin{array}{l}\text { Tobago/kidney stones } \\
\text { or urolithiasis }\end{array}$ & $\begin{array}{l}\text { stamp fern, egyptian } \\
\text { secret }\end{array}$ & leaves/decoction & 7.5 & 150.0 & 150.0 & 75.0 & 37.5 \\
\hline $\begin{array}{l}\text { Aristolochiaceae } \\
\text { Aristolochia trilobata L. } \\
\text { (019609) }\end{array}$ & fever & bejuco estrella & leaves/decoction & 8.8 & 176.5 & 176.5 & 88.3 & 44.0 \\
\hline $\begin{array}{l}\text { Commelinaceae } \\
\text { Tradescantia } \\
\text { spathacea Sw. } \\
\text { (019664) }\end{array}$ & Puerto Rico/psoriasis & sanguinaria & leaves/decoction & 2.8 & 56.0 & 56.0 & 28.0 & 14.0 \\
\hline $\begin{array}{l}\text { Zingiberaceae Costus } \\
\text { specious (J. König) Sm. } \\
c, d \text { (019660) }\end{array}$ & Puerto Rico/nephritis & $\begin{array}{l}\text { caña amarga, } \\
\text { insulina }\end{array}$ & leaves/decoction & 2.4 & 47.3 & 47.3 & 23.7 & 11.8 \\
\hline $\begin{array}{l}\text { Zingiberaceae } \\
\text { Tapeinochilus } \\
\text { ananassae K. Schum. } \\
\text { (019553) }\end{array}$ & Puerto Rico & insulina & leaves/decoction & 3.1 & 61.5 & 61.5 & 30.5 & 15.3 \\
\hline $\begin{array}{l}\text { Myrtaceae Syzygium } \\
\text { jambos (L.) Alston }^{d} \\
\text { (019663) }\end{array}$ & Puerto Rico & Pomarrosa del río & leaves/decoction & 2.1 & 41.8 & 41.8 & 20.9 & 10.5 \\
\hline
\end{tabular}

a) Reported in $20 \%$ or more of the interviews for a given ailment.

b) Extracts concentration/disc: disc $1-\mu \mathrm{g} / \mu \mathrm{L}$ in the re-dissolved lyophilized extract at the final concentration, discs 2 and $3-\mu \mathrm{g} / \mu \mathrm{L}$ in $50 \%$ and $25 \%$ dilutions of the re-dissolved extract, respectively.

c) As reported in the ethnobotanical literature in Puerto Rico to exhibit antimicrobial properties.

d) As reported in ethnopharmacological survey in Puerto Rico as an adjuvant for diabetes.

\section{Antimicrobial activity determination using the disc diffusion assay}

The disc preparation was performed following the procedure outlined by the British Society for Antimicrobial Chemotherapy in their Methods for Antimicrobial Susceptibility Testing Version 7, January 2008 [15]. A single bacterial colony was removed from a streak plate of
Trypticase soy agar (TSA, BD Biosciences) and incubated in Luria broth (LB, Difco) overnight with shaking at $37^{\circ} \mathrm{C}$. A bacterial suspension in $2 \mathrm{~mL}$ of distilled $\mathrm{H}_{2} \mathrm{O}$ was prepared and adjusted to a density of $0.5 \mathrm{McF}$ arland units, which correspond to $1.5 \times 10^{8} \mathrm{CFU} / \mathrm{mL}$. The suspension was then plated onto Mueller-Hinton agar (Difco), followed by disk deposition and incubation at 
$37^{\circ} \mathrm{C}$ for 20 hours. Growth inhibition was determined by measuring the diameter of the inhibition surrounding each disc. The relative inhibition was calculated for each extract and is represented as the percentage difference of inhibition between the positive control (antibiotic) and the extract. All of the experiments were performed in triplicate.

\section{Minimum inhibitory concentration (MIC) determination}

The MIC is defined as the lowest concentration of antimicrobial that can inhibit the visible growth of a microorganism after overnight incubation (British Society for Antimicrobial Chemotherapy). Extracts that showed inhibition in the disc diffusion assay were further analyzed according to the procedure of Velmonte et al. with some modifications [16]. The bacterial species tested were $S$. saprophyticus (ATCC 15305), S. aureus (ATCC 6341), P. aeruginosa (ATCC 7700) and P. vulgaris (ATCC 6896). MIC was determined for the extracts of Syzygium jambos, Pityrogramma calomelanos, Tapeinochilus ananassae and Gossypium barbadense. Stock solutions of lyophilized aqueous extracts were serially diluted to obtain working solutions with concentrations ranging from 2.0 to 0.003 $\mathrm{mg} / \mathrm{mL}$. Wells in a sterile 96-well plate were inoculated with Luria Broth (LB) medium in the absence of bacteria (blank control sample), bacteria with medium (positive control sample), bacteria with medium and the extract dilutions (experimental samples), background control (samples consisting of medium with extract dilutions to eliminate background extract absorbance), and bacteria with Streptomycin at $10 \mathrm{mg} / \mathrm{mL}$ (negative control samples). Bacterial suspensions containing $5 \times 10^{4} \mathrm{CFU} / \mathrm{mL}$ of Staphylococcus aureus (ATCC 6341), Staphylococcus saprophyticus (ATCC 15305), Proteus vulgaris (ATCC 6896) or Pseudomonas aeruginosa (ATCC 7700) were added to each well. The 96-well plates were incubated at $37^{\circ} \mathrm{C}$ for $18-20$ hours. The absorbance at $625 \mathrm{~nm}$ was measured for each plate using a microplate reader, and background-subtracted with the background of the control (bacteria and medium). Then, the absorbance of the extracts was compared to the absorbance of the positive and negative control (Streptomycin $10 \mathrm{mg} / \mathrm{mL}$ ) wells. The MIC was the concentration in the wells that showed an absorbance lower to the control well and that also gave a p-value of 0.001 or less after statistical analysis.

Minimum bactericidal concentration (MBC) determination The minimum bactericidal concentration (MBC) value is defined as the extract concentration at which no bacterial growth is observed in the agar nutrient plates, similar to the negative control Streptomycin $(10 \mathrm{mg} / \mathrm{mL})$. The effective concentration of the extracts in the experimental wells, as determined using the MIC assay, was used to inoculate LB plates using a sterile swab and incubated overnight at $37^{\circ} \mathrm{C}$. Plates containing positive (bacteria with medium) and negative (bacteria with $10 \mathrm{mg} / \mathrm{mL}$ Streptomycin) controls for each bacterial species were also prepared. The lowest concentration of the extract at which no bacterial growth was observed was recorded as the MBC. The MBC experiments were performed in triplicate.

\section{Statistical analysis}

The inhibition data are presented as the percentage of the positive control +/- SD. The MIC values are the concentrations of each plant that were statistically significant (value of 0.001 or less) compared with the control samples.

\section{Results and discussion}

The plant extracts listed in Table 1 were studied for their antimicrobial activities against Staphylococcus saprophyticus (ATCC 15305), Staphylococcus aureus (ATCC 6341), Pseudomonas aeruginosa (ATCC 7700), Proteus vulgaris (ATCC 6896), Escherichia coli (ATCC 4157), Haemophilus influenza (ATCC 8142), and the fungus Candida albicans (ATCC 752). Of the 13 plant extracts tested, data corresponding to the extracts that showed microbial growth inhibition in the disc diffusion assays will be discussed. These extracts include $G$. barbadense fruit juice and the decoctions of $P$. calomelanos, T. ananassae, and S. jambos (Figure 1). The bacterial species inhibited by these extracts were $S$. saprophyticus (ATCC 15305), S. aureus (ATCC 6341), P. aeruginosa (ATCC 7700) and P. vulgaris (ATCC 6896).

Juice prepared from unripe G. barbadense fruit exhibited more than $25 \%$ growth inhibition of the two Gram-positive bacteria S. aureus (ATCC 6341) and S. saprophyticus (ATCC 15305) relative to Streptomycin treatment which showed $100 \%$ inhibition at $5 \mathrm{mg} / \mathrm{mL} . S$. aureus (ATCC 6341) has been isolated from the discharge produced during an otitis media infection, which provides a rationale for the use of G. barbadense juice (juice from the unripe fruit) as an herbal remedy for this infection [17]. The antimicrobial activity was observed at a concentration of $7 \mathrm{mg} / \mathrm{mL}$, the lowest concentration tested (Figure 1A). The MIC values that were determined in this study for G. barbadense against $S$. aureus (ATCC 6341) and S. saprophyticus (ATCC 15305) did not meet the p-value of 0.001 or less used in our analyses. This result contrasts with a study of medicinal plants from Yemen in which aqueous extracts from $G$. barbadense were not active (MIC values $>1,000 \mu \mathrm{g} / \mathrm{mL}$ ) against $S$. aureus and E. coli and showed low activity $(\mathrm{MIC}=1000 \mu \mathrm{g} / \mathrm{mL})$ against $P$. aeruginosa and other bacterial strains [18]. In our study, no measureable MBC was observed for either bacterial species. Treatment for otitis media using herbal remedies has been very difficult. 

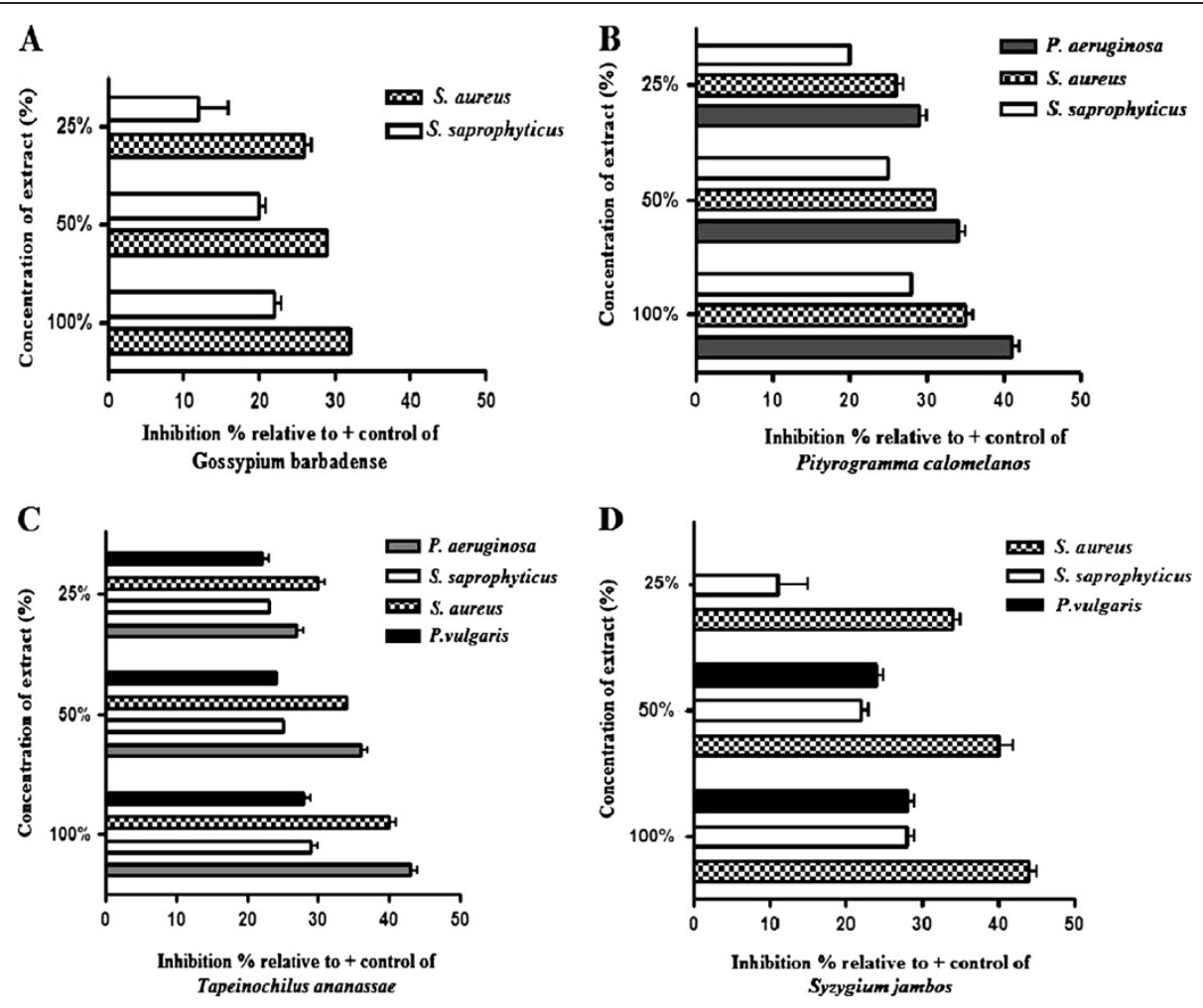

Figure 1 Herbal remedies in the Caribbean that showed antimicrobial activities. Inhibition was calculated as percentages relative to the positive control, Streptomycin- treated discs. A) G. barbadense juice; B) P. calomelanos decoction; C) T. ananassae decoction and D) S. jambos decoction.

A study using an ethanolic extract of the commonly used herb for infectious diseases, Echinacea purpurea roots and seeds, did not show a decrease in the risk of otitis media infection [19]. Nevertheless, naphthofuran analogues and biologically active terpenoids from G. barbadense are known to exhibit growth-inhibitory and antibacterial activities [20,21]. In addition, the essential oil has been reported to show moderate activities against $S$. aureus, E. coli and the fungus C. albicans [22]. Although the antimicrobial activity in the oil might be due to the major components or to synergy between major and minor components of the oil, $\alpha$-pinene, which is a terpene that comprises $12.8 \%$ of the oil, has shown efficient antimicrobial properties.

The decoction of P. calomelanos (at the lowest concentration of $37.5 \mathrm{mg} / \mathrm{mL}$ ) inhibited the growth of $P$. aeruginosa (ATCC 7700), S. aureus (ATCC 6341) and $S$. saprophyticus (ATCC 15305) by $2 \%-20 \%$ relative to Streptomycin which showed $100 \%$ inhibition at $5 \mathrm{mg} /$ $\mathrm{mL}$ (Figure 1B). The MIC for $P$. aeruginosa (ATCC 7700) was $2 \mathrm{mg} / \mathrm{mL}(\mathrm{p}=0.0001)$; however, for $S$. aureus (ATCC 6341) and S. saprophyticus (ATCC 15305), the MIC values were not statistically significant (Table 2). None of the concentrations that were tested showed bactericidal activity. P. calomelanos is traditionally used to treat kidney stones. The bacterium $P$. aeruginosa has been associated with biofilm formation on kidney stones, which leads to urinary infections [23]. The use of $P$. calomelanos decoctions to treat kidney stones could be related to the growth inhibition of $P$. aeruginosa, which may justify the use of this treatment as an herbal medicine. Studies that focused on several fern families have demonstrated that ethanol and methanol extracts from these plants exhibit antibacterial properties [24,25].

Table 2 MIC (p-value 0.001 or less) and MBC of extracts that showed inhibition in the disc diffusion assays ${ }^{a}$

\begin{tabular}{lllll}
\hline Plant extracts & Bacteria & $\begin{array}{l}\text { MIC } \\
(\mathbf{m g} / \mathbf{m L})\end{array}$ & p-value & $\begin{array}{l}\text { MBC } \\
(\mathbf{m g} / \mathbf{m L})\end{array}$ \\
\hline T. ananassae & P. aeruginosa & 0.5 & 0.0002 & $\mathrm{ND}^{\mathrm{b}}$ \\
& P. vulgaris & 0.5 & 0.0001 & 2.0 \\
& S. aureus & 0.015 & 0.001 & $\mathrm{ND}^{\mathrm{b}}$ \\
& S. saprophyticus & 2.0 & 0.0004 & 2.0 \\
P. calomelanos & P. aeruginosa & 2.0 & 0.0001 & $\mathrm{ND}^{\mathrm{b}}$ \\
S. jambos & S. aureus & 0.5 & 0.00001 & 1.0 \\
& S. saprophyticus & 0.5 & 0.001 & 2.0 \\
& P. vulgaris & 0.031 & 0.001 & 1.0
\end{tabular}

a) All the extracts that showed inhibition in the disc diffusion assay were analyzed against the bacteria isolates S. saprophyticus (ATCC 15305), S. aureus (ATCC 6341), P. aeruginosa (ATCC 7700) and P. vulgaris (ATCC 6896). b) $N D$, Not detected. 
Recently, a study reported the antimicrobial and modulatory antibiotic activity of the ethanol extract and the methanolic fraction from the leaves of $P$. calomelanos [26]. Neither preparation demonstrated antimicrobial activity that was clinically relevant to fungi or bacteria (MIC $>1024 \mu \mathrm{g} / \mathrm{mL})$. However, in the modulation assay, both extracts modulated most of the antibiotics tested against $S$. aureus. The present study only tested aqueous extracts as a way to validate the traditional remedies employed by the surveyed population and is the first to report the antimicrobial activities of $P$. calomelanos decoctions. Phytochemical analysis of aqueous extracts of $P$. calomelanos has revealed the presence of carbohydrates and coumarin [27]. Although data regarding the specific antibiotic properties of coumarins are scarce, antimicrobial activity against bacteria, fungi and viruses has previously been reported for this class of phytochemicals [3]. Conversely, polysaccharides are commonly more effective as inhibitors of pathogen adsorption and would not be identified in the screening techniques commonly used.

The decoction of $T$. ananassae at $15.3 \mathrm{mg} / \mathrm{mL}$, the lowest concentration tested, inhibited the growth of two Gram-positive and two Gram-negative bacterial strains by $22 \%-30 \%$ compared to the $100 \%$ inhibition of Streptomycin at $5 \mathrm{mg} / \mathrm{mL}$ (Figure 1C). Specifically, the growth inhibition values of $P$. aeruginosa (ATCC 7700), $S$. saprophyticus (ATCC 15305), S. aureus (ATCC 6341) and $P$. vulgaris (ATCC 6896) were $29 \%, 22 \%, 32 \%$ and $24 \%$, respectively. The MIC values for $T$. ananassae were $0.5 \mathrm{mg} / \mathrm{mL}$ for $P$. aeruginosa (ATCC 7700), and $P$. vulgaris (ATCC 6896) ( $\mathrm{p}=0.0002$ and 0.0001 , respectively), $0.015 \mathrm{mg} / \mathrm{mL}$ for $S$. aureus (ATCC 6341) ( $\mathrm{p}=$ 0.001 ) and $2.0 \mathrm{mg} / \mathrm{mL}$ for $S$. saprophyticus (ATCC 15305) $(\mathrm{p}=0.0004) \quad$ (Table 2). T. ananassae displayed bactericidal activity against $P$. vulgaris (ATCC 6896) and S. saprophyticus (ATCC 15305) at concentrations of 2.0 $\mathrm{mg} / \mathrm{mL}$ for both species (Table 2). Our study showed that T. ananassae inhibits the growth of pathogens associated with opportunistic infections of burns and skin infections such as $P$. aeruginosa and $S$. aureus, respectively [28]. $P$. aeruginosa has become an important cause of infection, especially in immunocompromised patients, such as diabetic and cancer patients [29]. The antibiotic activities of $T$. ananassae are important because people with diabetes are vulnerable to infections as a result of low blood flow to the extremities [30] and because of certain types of neuropathy that cause dry and cracked skin. Additional antimicrobial activity has been reported for $T$. ananassae against the Gram-negative bacterium Helicobacter pylori [31].

Decoctions of Syzygium jambos leaves inhibited S. aureus (ATCC 6341) and S. saprophyticus (ATCC 15305) by $34 \%$ and $11 \%$, respectively, at the lowest concentration studied $(10.5 \mu \mathrm{g} / \mu \mathrm{L})$ relative to Streptomycin which showed $100 \%$ inhibition at $5 \mathrm{mg} / \mathrm{mL}$. S. jambos at $20.9 \mathrm{mg} /$ $\mathrm{mL}$ also inhibited the Gram-negative $P$. vulgaris (ATCC 6896 ) by $24 \%$ relative to Streptomycin which showed $100 \%$ inhibition at $5 \mathrm{mg} / \mathrm{mL}$ (Figure 1D). The MIC value for $S$. aureus (ATCC 6341) and S. saprophyticus (ATCC 15305) were $0.5 \mathrm{mg} / \mathrm{mL}(\mathrm{p}=0.00001$ and 0.001 , respectively), and the MIC value for P. vulgaris (ATCC 6896) was $0.031 \mathrm{mg} /$ $\mathrm{mL}(\mathrm{p}=0.001)$ (Table 2). S. jambos was the only extract that showed bactericidal activity against all of the isolates that were tested. The MBC value for both $S$. aureus (ATCC 6341) and P. vulgaris (ATCC 6896) was $1.0 \mathrm{mg} / \mathrm{mL}$, and the MBC value for S. saprophyticus (ATCC 15305) was $2.0 \mathrm{mg} / \mathrm{mL}$ (Table 2). Previously, Lin et al. reported that aqueous and acetone extracts from the bark of Syzygium jambos had activity against several species of $S$. aureus with MIC values that ranged from 0.50 to $0.75 \mathrm{mg} / \mathrm{mL}$ and suggested that more active inhibitory compounds are found in the leaves $(0.21$ to $0.83 \mathrm{mg} / \mathrm{mL})$ than in the bark [32]. Additionally, methanolic extracts of Syzygium aromaticum showed inhibition against S. aureus, Staphylococcus epidermidis, Streptococcus pyogenes, Salmonella enterica serovar Typhi and P. aeruginosa with MICs ranging from 31.25-250 $\mu \mathrm{g} / \mathrm{mL}$ [33]. We did not find antimicrobial activity against $P$. aeruginosa, which suggests that variation in the polarities of the extraction solvents and the preparation methods used to make the extracts that were studied may account for the difference in the activities of these two species.

For nearly all of the plant species that have significant uses but that did not show antimicrobial activity, there is evidence that their activity varies significantly with the polarity and the concentration of the extracts, which in turn determines the phytochemicals responsible for the antibiotic effects [3,34]. For instance, the antimicrobial effects of hydroalcoholic extracts from the leaves of Plectranthus amboinicus have been reported against $S$. aureus with a MIC of $9.3 \mathrm{mg} / \mathrm{mL}$ [35]. In another study [36], seven out of ten $S$. aureus strains obtained from exudates of otitis externa were sensitive to $P$. amboinicus extracts at concentrations ranging from 1.25 to $5.0 \mathrm{mg} /$ $\mathrm{mL}$. In particular, the essential oil of $P$. amboinicus was active against two of the strains tested at $4 \%$ and $8 \%(\mathrm{w} /$ $\mathrm{V})$. This result is noteworthy because the decoction, which corresponds to the traditional preparation that is used, significantly resembles the fraction obtained from a steam distillation, which carries the essential oils that would have been inactive in solution at the concentrations obtained in this study $(5.3-21.3 \mu \mathrm{g} / \mu \mathrm{L})$. The authors do not report the polarity of the extracts, although the use of hydroalcoholic extracts was suggested.

The polar methanolic extracts from the leaves and bark of Aristolochia trilobata showed activity against $E$. coli with a MIC value of $2.5 \mathrm{mg} / \mathrm{mL}$ [37]. This MIC 
value is comparable to the concentration of the decoctions tested in this study, which were 3.22 and $3.53 \mathrm{mg} /$ $\mathrm{mL}$ for the stem and leaves, respectively. It is known that methanol extractions are more exhaustive than those of the aqueous or less polar organic and non-polar organic solvents. Therefore, the compounds that are responsible for the observed activity could be absent from the aqueous decoctions. However, the authors previously reported that the traditional use of this plant species has to be discouraged due to the mutagenic and possibly human carcinogenic properties of the aristolochic acids present in the methanol extracts and possibly in the water preparations of aerial parts of the plant.

Serrulatane quinonoid biflorin, which is isolated from the root tissue of Capraria biflora, has been reported to exhibit antimicrobial activities against Gram-positive bacteria [38]. This activity is consistent with the traditional use to treat conjunctivitis, which may be associated with infections by S. aureus, S. epidermidis and Propionibacterium spp., among others. Thus far, the activity of aqueous extracts from the leaves has not been reported.

Aqueous extracts from the rhizomes of Costus speciosus have been reported to exhibit antimicrobial activity against S. aureus at a concentration of $200 \mathrm{mg} / \mathrm{mL}$ [39]. The report describes the traditional system of administration studied herein, but given that the concentrations tested in our study varied from $11.8-47.3 \mu \mathrm{g} / \mu \mathrm{L}$, a continuous administration of the decoction would be required to explain the traditional use for kidney infections.

Although there are several reports of the broad spectrum antimicrobial activity of Cucurbita moschata oil and seed extracts, no reports were found on the activity of decoctions from the leaves [40]. Likewise, only ethanol and acetone:ethyl acetate (1:1) extracts of the aerial parts of $H$. rosa-sinensis have been studied previously [41,42]. The reported MIC and MBC values for the ethanolic extract of the flowers against $S$. aureus were $20 \mathrm{mg} / \mathrm{mL}$. Thus, although the activities reported indicate that antimicrobial compounds are present in more polar solvents, higher concentrations than that found in the traditional remedy are needed to assess the antibacterial activity.

The results for Plantago major are similar to those described above. That is, at a concentration of $2 \mathrm{mg} / \mathrm{mL}$ in the hydroalcoholic extract, which is higher than those found in the decoctions $(7.2-28.7 \mu \mathrm{g} / \mu \mathrm{L})$, the authors reported MIC values of $1 \mathrm{mg} / \mathrm{mL}$ for $S$. aureus and $>1$ $\mathrm{mg} / \mathrm{mL}$ against $E$. coli, $P$. aeruginosa, $C$. albicans and others [43]. Furthermore, the antibacterial properties of lyophilized and fresh water extracts of Abelmoschus esculentus were effective against all bacterial strains tested, including S. aureus, E. coli and P. aeruginosa. The fresh extract displayed better antibacterial properties than the lyophilized extract [44]. The MIC values for peeled and unpeeled A. esculentus were 6.4 and $12.8 \mathrm{mg} /$ $\mathrm{mL}$ for $S$. aureus and $P$. aeruginosa, respectively. In this case, the lipid fraction of $A$. esculentus was found to be responsible for the antibacterial properties, whereas the protein and polysaccharide fractions displayed no antimicrobial activity. The concentration of the $A$. esculentus decoction that was prepared in this study according to the traditional use reported during the ethnopharmacological survey was $12.6 \mathrm{mg} / \mathrm{mL}$.

This study did not find antimicrobial activity that validates the traditional use of several herbal decoctions that showed significant use during TRAMIL ethnopharmacological surveys. Two separate analyses, the disc diffusion and the MIC assays, demonstrated that fewer than $33 \%$ of the herbal remedies that were examined exhibited antibacterial activities. This result is not discouraging because several factors, in addition to those studied, could determine the effectiveness of the extracts. First, the extracts could contribute to the treatment of disease, not necessarily by exerting an antibacterial response but by promoting an anti-inflammatory response. This effect was shown by Yang and collaborators, who demonstrated the antimicrobial and anti-inflammatory properties of the essential oils from Citrus sunki [45]. In addition, aqueous extracts are typically less potent formulations than those prepared with organic solvents such as methanol [46]. The solvent and the extraction system may modify the final results as described in the study of Argemone mexicana [47]. In this study, although the various solvent extracts examined were effective, the methanolic extracts showed maximum inhibition against the tested microorganisms, followed by hot aqueous extracts and cold aqueous extracts.

\section{Conclusions}

This study examined the inhibitory activity of Caribbean herbal remedies, which are treatments that are generally used by the surveyed populations for otitis media, kidney stones, skin burns, fever and conjunctivitis, which are associated with infections caused by Gram-positive and Gram-negative bacteria. Considering that antimicrobials are typically regarded as bactericidal if the $\mathrm{MBC}$ is nearly four times the MIC, this study identified the novel bactericidal properties of $T$. ananassae and S. jambos decoctions, which are commonly used as diabetes adjuvants in Puerto Rico. The bactericidal activities of these preparations will be extremely useful when treating patients with compromised immune systems, such as diabetes patients. Additionally, this article is the first report of the antimicrobial activities of G. barbadense and P. calomelanos decoctions. The findings that are reported here, which are the result of a screen for the antimicrobial activities of traditional Caribbean herbal remedies, will be presented to the TRAMIL program to inform future TRADIF activities. 


\section{Competing interests}

The authors state no conflict or competing interests are associated with the present study.

\section{Authors' contributions}

CLM and JGS designed the study and contributed to the preparation of the manuscript and data analysis. CLM carried out the inhibition assays. JGS collected plants for the study. IB supplied the results of ethnopharmacological surveys. All the authors approved and reviewed the final draft of the manuscript.

\section{Acknowledgements}

The authors wish to thank all the families who participated in the ethnopharmacological surveys throughout the Caribbean region, the RISE Program at UPR-Cayey for their continued support to our research group, $\mathrm{Mr}$. José Sustache, Director of the George Proctor Herbarium (SJ) and Mr. Héctor Serrano, Resident Biologist at Carite National Forest. This work was conducted with support from the Institute of Interdisciplinary Research at UPR-Cayey and the USA National Institutes of Health RIMI Program Grant \#1P2MD001112-0.

\section{Author details}

${ }^{1}$ Institute of Interdisciplinary Research, University of Puerto Rico, Cayey, \#205 Antonio R. Barceló Ave, Cayey, PR 00736, Puerto Rico. ²University of French Antilles and Guyana, UFR Faculty of Science, TRAMIL, F-97157, Pointe à Pitre, Guadeloupe Cedex, Guadeloupe. ${ }^{3}$ Department of Chemistry, University of Puerto Rico, Cayey, \#205 Antonio R. Barceló Ave, Cayey, PR 00736, Puerto Rico. ${ }^{4}$ Present address: San Juan Bautista Medical School, Department of Microbiology, Caguas 00727, Puerto Rico.

Received: 21 September 2012 Accepted: 31 May 2013

Published: 4 June 2013

\section{References}

1. Walsh FM, Amyes SG: Microbiology and drug resistance mechanisms of fully resistant pathogens. Curr Opin Microbiol 2004, 7(5):439-444.

2. Cowan MM: Plant products as antimicrobial agents. Clin Microbiol Rev 1999, 12:564-582

3. Coutinho HD, Costa JG, Lima EO, Falcão-Silva VS, Siqueira JP Jr: Herbal therapy associated with antibiotic therapy: potentiation of the antibiotic activity against methicillin--resistant Staphylococcus aureus by Turnera ulmifolia L. BMC Complement Altern Med 2009, 8(9):13.

4. Israr F, Hassan F, Naqvi BS, Azhar I, Jabeen S, Hasan SM: Report: Studies on antibacterial activity of some traditional medicinal plants used in folk medicine. Pak J Pharm Sci 2012, 25(3):669-674

5. Helmer EH, Ramos O, del Mar López T, Díaz W: Mapping the forest type and land cover of Puerto Rico, a component of the Caribbean biodiversity hotspot. Caribbean Journal of Science 2002, 38:165-183.

6. Germosén-Robineau L, Delens M, García-González M, Herrera J, Morón F, Sáenz-Campos D, Solís P: Farmacopea Vegetal Caribeña. 2nd edition. Santo Domingo: Editora y Papelería Josué; 2005.

7. Boulogne I, Germosén-Robineau L, Ozier-Lafontaine H, Fleury M, LorangerMerciris G: TRAMIL Ethnopharmalogical survey in Les Saintes, Guadeloupe (French West Indies): a comparative study. J Ethnopharmacol 2011, 133:1039-1050

8. Nuñez E: Plantas Medicinales de Puerto Rico. Río Piedras: Editorial de la Universidad de Puerto Rico; 1989.

9. Benedetti MD: Sembrando y sanando en Puerto Rico. Cayey: Verde Luz; 1996.

10. Carton JA, Maradona JA, Nuno FJ, Fernandez-Alvarez R, Perez-Gonzalez F, Asensi V: Diabetes mellitus and bacteraemia: a comparative study between diabetic and non-diabetic patients. Eur J Med 1992, 1(5):281-287.

11. Chao CY, Cheing GL: Microvascular dysfunction in diabetic foot disease and ulceration. Diabetes Metab Res Rev 2009, 25(7):604-614

12. De Bona KS, Bellé LP, Bittencourt PE, Bonfanti G, Cargnelluti LO, Pimente VC, Ruviaro AR, Schetinger MR, Emanuelli T, Moretto MB: Erythrocytic enzymes and antioxidant status in people with type 2 diabetes: beneficial effect of Syzygium cumini leaf extract in vitro. Diabetes Res Clin Pract 2011, 94(1):84-90.

13. Rivero-Cruz JF: Antimicrobial compounds isolated from Haematoxylon brasiletto. J Ethnopharmacol 2008, 119(1):99-103.
14. UofMHealth.org: US hospitals are all over the map when it comes to preventing the most common type of in-hospital infection; 2008. http:// www.uofmhealth.org/node/666938.

15. BSAC: Methods for Bacterial Susceptibility Testing (Version 7); 2010. http://bsac. org.uk/wp-content/uploads/2012/02/version_7.pdf

16. Velmonte M, Gonzaga A, Darvin C: Local production of Low cost quality antibiotic susceptibility disks for the Philippines. Phil J Microbiol Infect Diseases 1988, 17(2):66-75.

17. Abera B, Biadeglegne F: Antimicrobial resistance patterns of staphylococcus aureus and Proteus spp. Isolated from otitis media at bahir Dar regional laboratory, north west Ethiopia. Ethiop Med J 2009, 47(4):271-276.

18. Al-Fatimi M, Wurster M, Schröder G, Lindequist U: Antioxidant, antimicrobial and cytotoxic activity of selected medicinal plants from Yemen. J Ethnopharmacol 2007, 111:657-666.

19. Wahl RA, Aldous MB, Worden KA, Grant KL: Echinacea purpurea and osteopathic manipulative treatment in children with recurrent otitis media: a randomized controlled trial. BMC Complement Altern Med 2008, 8:56

20. Kanlayavattanakul M, Lourith $\mathrm{N}$ : Therapeutic agents and herbs in topical application for acne treatment. Int J Cos Sci 2011, 3:289-297.

21. Kirilmiş C, Koca M, Servi S, Gür S: Synthesis and antimicrobial activity of Dinaphtho[2,1-b]furan-2-yl-methanone and their oxime derivatives. Turk $J$ Chem 2009, 33:375-384.

22. Essien EE, Aboaba SO, Ogunwande IA: Constituents and antimicrobia properties of the leaf essential oil of Gossypium barbadense (Linn.). J Med Plant Res 2011, 5:702-705.

23. Furuhata $M$, Iwamura $M, B a b a ~ S$, Inoue $M$ : Combined effect of clarithromycin and imipenem/cilastatin against urinary biofilm infection after pyeloplasty. Int J Urol 2004, 10(4):228-230.

24. Shokeen P, Bala M, Tandon V: Evaluation of the activity of 16 medicinal plants against Neisseria gonorrhoeae. Int J Antimicrob Agents 2009, 33(1):86-91

25. Khan MR, Omoloso AD: Antibacterial and antifungal activities of angiopteris evecta. Fitoterapia 2008, 79(5):366-369.

26. Souza TM, Morais-Braga MFB, Costa JGM, Saraiva AAF, Coutinho HDM: Enhancement of antimicrobial activity of antibiotics and antifungals by the use of natural products from pityrogramma calomenanos (L.) link. Arch. Biol. Sci 2012, 64:43-48.

27. Mithraja MJ, Antonisamy JM, Mahesh M, Paul ZM, Jeeva S: Chemical diversity analysis on some selected medicinally important pteridophytes of Western Ghats, India. Asian Pacific J Trop Biomed 2012, 2((Suppl 1)):S34-S39.

28. Church D, Elsayed S, Reid O, Winston B, Lindsay R: Burn wound infections Clin Microbiol Rev 2006, 19:403-434.

29. Varaiya A, Kulkarni M, Bhalekar P, Dogra J: Incidence of carbapenemresistant pseudomonas aeruginosa in diabetes and cancer patients. Indian J Med Microbiol 2008, 26(3):238-240.

30. Nielson DL, Ali Y: Diabetic foot infections: time to change the prognostic concept. J Am Podiatr Med Assoc 2009, 99(5):454-458.

31. Ndip RN, Malange Tarkang AE, Mbullah SM, Luma HN, Malongue A, Ndip LM, Nyongbela K, Wirmum C, Efange SM: In vitro anti-Helicobacter pyroli activity of extracts of selected medicinal plants from North West Cameroon. J Ethnopharmacol 2007, 114(3):452-457.

32. Lin WH, Chang ST, Chang SC, Chang HT: Isolation of antibacterial diterpenoids from Cryptomeria japonica bark. Nat Prod Res 2008 22:1085-1093.

33. Ali NH, Faizi S, Kazmi SU: Antibacterial activity in spices and local medicinal plants against clinical isolates of Karachi. Pharm Biol 2011 49(8):833-839.

34. Tiwari P, Kumar B, Kaur M, Kaur G, Kaur H: Phytochemical screening and extraction: a review. Int Pharma Sci 2011, 1:98-106.

35. Gurgel APAD, da Silva JG, Grangeiro ARS, Xavier HS, Oliveira RAG, Pereira MSV, de Souza IA: Antibacterial effects of Plectranthus amboinicus (Lour.) Spreng (Lamiaceae) in Methicillin resistant Staphylococcus aureus (MRSA). Lat Am J Pharm 2009, 28:460-464.

36. Nogueira JCR, Melo-Diniz MF, Lima EO: In vitro antimicrobial activity of plants in acute otitis externa. Rev Bras Otorrinolaringol 2008, 74:118-124.

37. Camporese A, Balick MJ, Arvigo R, Esposito RG, Mordellino N, De Simone F, Tubaro A: Screening of anti-bacterial activity of medicinal plants from Belize (Central America). J Ethnopharmacol 2003, 87:103-107.

38. Smith JE, Tucker D, Watson K, Jones GL: Identification of antibacterial constituents from the indigenous Australian medicinal plant Eremophila duttonii F. Muell. (Myoporaceae). J Ethnopharmacol 2007, 112:386-393. 
39. Saraf A: Phytochemical and antimicrobial studies of medicinal plant Costus speciosus (Koen.). E-J.Chem 2010, 7(S1):S405-S413.

40. Caili F, Huan S, Quanhong L: A review on pharmacological activities and utilization technologies of pumpkin. Plant Foods Human Nutr 2006, 61:73-80.

41. Seyyednejad SM, Koochak H, Darabpour E, Motamedi H: A survey on Hibiscus rosa-sinensis, Alcea rosea L. and Malva neglecta Wallr as antibacterial agents. Asian Pacific J Trop Med 2010, 3:351-355.

42. Facey PC, Pascoe KO, Porter RB, Jones AD: Investigation of plants used in Jamaican folk medicine for anti-bacterial activity. J Pharm Pharmacol 1999, 51:1555-1560.

43. Holetz FB, Pessini GL, Sanches NR, Garcia-Cortez DA, Nakamura CV, DiasFilho BP: Screening of some plants used in the brazilian folk medicine for the treatment of infectious diseases. Mem Inst Oswaldo Cruz 2002, 97:1027-1031

44. De Carvalho CCCR, Almeida-Cruz P, da Fonseca MMR, Xavier-Filho L: Antibacterial properties of the extract of Abelmoschus esculentus. Biotechnol Bioprocess Engineer 2011, 16:971-977.

45. Yang EJ, Kim SS, Moon JY, Oh TH, Baik JS, Lee NH, Hyun CG: Inhibitory effects of Fortunella japonica var. margarita and Citrus sunki essential oils on nitric oxide production and skin pathogens. Acta Microbiol Immunol Hung 2010, 57(1):15-27.

46. Parekh J, Karathia N, Chanda S: Screening of some traditionally used medicinal plants for potential antibacterial activity. Indian J Pharm Sci 2006, 68(6):832-834.

47. Bhattacharjee I, Chatterjee SK, Chatterjee S, Chandra G: Antibacterial potentiality of Argemone mexicana solvent extracts against some pathogenic bacteria. Mem Inst Oswaldo Cruz 2006, 101:645-648.

doi:10.1186/1472-6882-13-126

Cite this article as: Luciano-Montalvo et al: A screening for antimicrobial activities of Caribbean herbal remedies. BMC Complementary and Alternative Medicine 2013 13:126.

\section{Submit your next manuscript to BioMed Central and take full advantage of:}

- Convenient online submission

- Thorough peer review

- No space constraints or color figure charges

- Immediate publication on acceptance

- Inclusion in PubMed, CAS, Scopus and Google Scholar

- Research which is freely available for redistribution 